\title{
Criterion Dendrometer as a non-destructive method for dendrometric estimations of native species in Western Amazon
}

The use of non-destructive approach for measurement in native environments is still a challenge given the ecology of natural forests. In this sense, the present study aimed to verify the accuracy of the Criterion RD $1000^{\circledR}$ optical dendrometer in the diametric and volumetric estimates of native species in a forest concession area, in Western Amazon. A total of 41 trees were measured at the FMU (Forest Management Unit) III, Flona (National Forest) of Jamari, Rondônia, Brazil, by nondestructive approach (standing tree), using Criterion RD $1000^{\circledR}$ optical dendrometers (indirect measurements), and by destructive approach (felled tree), using a taper and a caliper (indirect measurements). Diameter measurements were made along the commercial trunk every two meters from $1.30 \mathrm{~m}$ of the soil (DBH) by Smalian, and the volume was calculated by height classes and for all commercial trunk. The variables were compared by means tests, residue graphs and bias analysis, mean absolute differences and standard deviations of differences. Statistical differences were obtained for heights $>13,30 \mathrm{~m}$ and for the whole commercial trunk. For class and commercial volumes there was no difference between the tree volume determination approaches, however, there was a tendency to overestimate. Therefore, the non-destructive approach using Criterion RD $1000^{\circledR}$ is presented as an alternative for the tree volume determination, nevertheless, the observed tendencies, in greater heights, reflect the limitations of trunk visualization and the device operation.

\section{Dendrômetro Criterion como método não destrutivo para estimativas dendrométricas de espécies nativas na Amazônia Ocidental}

O uso dos métodos não destrutivos para mensuração em ambientes nativos ainda são um desafio dada a ecologia de florestas naturais. Nesse sentido, o presente estudo objetivou verificar a exatidão do dendrômetro óptico Criterion RD1000 ${ }^{\circledR}$ nas estimativas diamétricas e volumétricas de espécies nativas em área de concessão florestal, na Amazônia Ocidental. Foram mensuradas 41 árvores na UMF (Unidade de Manejo Florestal) III, Flona (Floresta Nacional) do Jamari, Rondônia, pelos métodos não destrutivos aproximados (árvore em pé), com uso de dendrômetros óptico Criterion RD1000 ${ }^{\circledR}$ (medida indireta), e destrutivo aproximado (árvore abatida) usando-se uma suta diamétrica (medida direta). Realizou-se a medição de diâmetros ao longo do fuste comercial a cada dois metros a partir de $1,30 \mathrm{~m}$ do solo (DAP) por Smalian, calculando-se o volume por classes de altura e para todo fuste comercial. As variáveis foram comparadas por teste de médias, gráficos de resíduos e análise de viés, média das diferenças absolutas e desvio padrão das diferenças. Obteve-se para diâmetros diferenças estatísticas nas alturas $>13,30$ m e para todo o fuste comercial. Para volumes de classes comerciais, não houve diferença entre as abordagens de determinação do volume das árvores, no entanto, houve uma tendência a superestimar. Portanto, a abordagem não destrutiva, utilizando o Criterion RD1000 ${ }^{\circledR}$, é apresentada como uma alternativa para a determinação do volume da árvore, no entanto, as tendências observadas, especialmente em alturas maiores, refletem as limitações da visualização do tronco e da operação do dispositivo.

Palavras-chave: Mensuração florestal; Árvores em pé; Árvores abatidas; Diâmetro das árvores; Determinação do volume de árvores.

Topic: Ciências Florestais

Reviewed anonymously in the process of blind peer.
Received: 02/10/2020

Approved: 20/11/2020
Scheila Cristina Biazatti (iD

Universidade Federal de Rondônia, Brasil http://lattes.cnpq.br/6379875277285936 http://orcid.org/0000-0001-5017-9780 scheila.biazatti@unir.br

\section{Rômulo Môra (iD)}

Universidade Federal de Mato Grosso, Brasil http://lattes.cnpq.br/3456015172126546 http://orcid.org/0000-0002-2234-6753

romulomef@yahoo.com.br

\section{Marta Silvana Volpato Sccoti (iD)}

Universidade Federal de Rondônia, Brasil http://lattes.cnpq.br/8802033326043600 http://orcid.org/0000-0001-5979-3218 martasccoti@unir.br

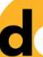

DOI: 10.6008/CBPC2179-6858.2020.006.0006

\author{
João Fideles de Brito Júnior (iD \\ Universidade Federal de Rondônia, Brasi \\ http://lattes.cnpq.br/4160488242507317 \\ http://orcid.org/0000-0002-5925-0667 \\ britojf.ro@gmail.com \\ Nayara dos Santos Queiroz (iD \\ Universidade Federal de Rondônia, Brasil \\ http://lattes.cnpq.br/4033339772058794 \\ http://orcid.org/0000-0002-9356-2816 \\ naah.queiroz95@gmail.com \\ Rafaella de Angeli Curto (iD \\ Universidade Federal Rural do Rio de Janeiro, Brasil \\ http://lattes.cnpq.br/7493748713385803 \\ http://orcid.org/0000-0001-5509-4655 \\ rafellacurto@yahoo.com.br
}

\section{Referencing this:}

BIAZATTI, S. C.; MÔRA, R.; SCCOTI, M. S. V.; BRITO JUNIOR, J. F.; QUEIROZ, N. S.; CURTO, R. A.. Criterion Dendrometer as a nondestructive method for dendrometric estimations of native species in Western Amazon. Revista Ibero Americana de Ciências Ambientais, v.11, n.6, p.59-70, 2020. DOI: http://doi.org/10.6008/CBPC2179$\underline{6858.2020 .006 .0006}$ 


\section{INTRODUCTION}

Forest measurements are important tools in natural forest management, mainly because they return quantitative knowledge regarding the forest, serving as guidance for forest planning (FREITAS et al., 1998; THAINES et al., 2010).

Some of the main limitations regarding the quantification of native forest productive potentials include difficulties in obtaining dendrometric variables, mainly tree height (COLPINI et al., 2009; THAINES et al., 2010; CYSNEIROS et al., 2017). The diameters, in some cases, do not follow a regularity along the trunk, influenced by the shape of trees, besides the presence of buttresses that can attribute tendencies in measurements (THAINES et al., 2010; BONAZZA et al., 2015).

In this sense, the volume quantification of trees in native forests is usually done by the destructive approach, by determining the volume of felled trees, through the rigorous cubing, since this allows measurement of dendrometric variables directly in the tree, being this activity carried out in storage yards (CYSNEIROS et al., 2017), or where trees are felled and sampling with the greatest number of measuring points along the trunk (THAINES et al., 2010; SILVA et al., 2014; TONINI et al., 2015).

Another alternative for tree volume determination of felled trees, would be using a non-destructive approach, using scaling to obtain direct diameter or aid of optical devices such as relascope, telerelascope, pentaprism and Criterion ${ }^{\circledast}$, which allow the indirect measurement of diameter with the standing tree, presenting efficacy in use for measurement in forest plantations (ARNEY et al., 1972; NICOLETTI et al., 2012; RODRIGUEZ et al., 2013; NICOLETTI et al., 2015; DALLA-CORTE et al., 2016). However, this non-destructive methodology of measurement and estimation of dendrometric variables of native species, mainly using optical devices, is not well studied and used in tropical native forests (SILVA, 2016).

However, it should be noted that even with the advantages of applying a non-destructive approach by optical devices, some use limitations are cited, such as difficulties in visualization and measurements in the highest positions of the trunk, density and branching of stands, proximity of trees in the surroundings and same direction of measurement, among others (WILLIAMS et al., 1999; CLARK et al., 2000; BONAZZA et al., 2015), indicating the need for studies that characterize the use and accuracy of optical dendrometers, especially in the measurement of dendrometric variables in natural forests.

Among the models of dendrometers instruments, there is the Criterion ${ }^{\circledR} \mathrm{RD} 1000$, which presents technological gains, compared to previous models, allowing, by a laser measurer with graduation bar to measure the diameter along the trunk with diameter measuring range up to $254 \mathrm{~cm}$ and accuracy from $6 \mathrm{~mm}$ up to $24 \mathrm{~m}$ depending on the distance, making possible the calculation of volume and other variables, such as biomass (CARDOSO et al., 2015; LASERTECH, 2019).

Thus, the importance of evaluating efficiency of using non-destructive approach in measurement of species in native environments, especially in the area of concession and forest management, considering the need to obtain reliable estimates of volume in planning stage of activities since these are the basis for execution of forest management on Amazon. 
In this context, the present study aimed to verify the accuracy of the Criterion RD1000 ${ }^{\circledR}$ optical dendrometer in diametric and volumetric estimates for native species in a forest concession area in the Western Amazon.

\section{MATERIALS AND METHODS}

\section{Location and study area characterization}

This study was carried out in two Annual Production Units (APU) located in the Forest Management Unit (FMU) III, in the National Jamari Forest (Flona), RO, Brazil, under a forest concession granted to the Amata SA company. APUs are located in the western and eastern portions of the FMU III and comprise a total area of $1,846.82$ ha and $2,455.69$ ha, respectively (AMATA, 2017) (Figure 1).

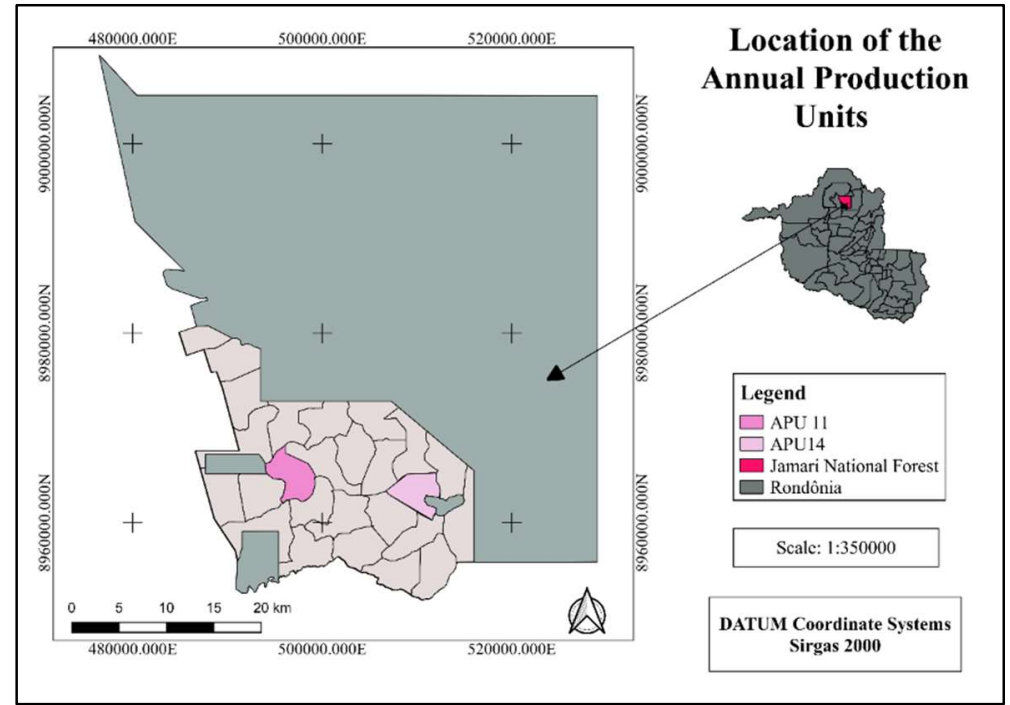

Figure 1: Localization of the study area at Unity of Forest Management III, Jamari Flona, RO.

According to Köppen's classification, the region presents a type Am climate, with a well-defined drought period, annual temperature means between 24 and $26^{\circ} \mathrm{C}$ and rainfall rates between 1900 and 2200 $\mathrm{mm}$, with a relief ranging from plane to slightly wavy and the highest altitude occurrence of up to $150 \mathrm{~m}$ (AMATA, 2009; ALVARES et al., 2013; CLIMATE-DATA, 2018). The main types of soils found in the area are Latosols and Argisols, with a predominance of Red-yellow Dystrophic Argisols, characterized as deep and well drained, with a clayey texture (MMA et al., 2005; AMATA, 2009).

The vegetation is predominantly classified as an Open Ombrophylous Forest, with Dense Ombrophylous Forest facies, characterized by the presence of spaced trees, a canopy approximately $40 \mathrm{~m}$ in height, large emergent trees at 45 to $55 \mathrm{~m}$ in height and palm trees in some areas (MMA et al., 2005; AMATA, 2009). According to the inventory carried out at APUs, some of the most frequent commercial value species in the area are: Faveira ferro (Dinizia excelsa Ducke), Embireira (Couratari stellata A. C. Sm.), Muiracatiara (Astronium lecointei Ducke), Garapeira (Apuleia leiocarpa (Vogel J.F.Macbr), Cumaru (Dipteryx odorata (Aubl.) Willd.), Angelim Pedra (Hymenolobium heterocarpum Ducke), Roxinho (Peltogyne paniculata Benth), Guariúba (Clarisia racemosa Ruíz \& Pav.), Tauari-Vermelho (Cariniana micrantha Ducke) and Cambará (Qualea paraensis Ducke) (AMATA, 2009; AMATA, 2017). 


\section{Data collection}

The species and trees to be measured were defined by the company's harvest planning analysis, evidencing the highest concentrations of individuals felled during the data collection period, occurred in July and August of 2017, when all the forest exploration activities were being carried out, allowing a greater availability of trees to be measured.

A total of 41 trees of four species with DBH (Diameter at $1.30 \mathrm{~m}$ of the soil) $\geq 50 \mathrm{~cm}$ were measured as standing trees (non-destructive approach) using the Criterion RD1000 ${ }^{\circledR}$ optical dendrometers (indirect measurements) and after as felled trees (destructive approach) using a taper and a caliper (direct measurements). The minimum cutting diameter was defined by the forest legislation. Commercial height (hc) was defined as the commercial height of $1.30 \mathrm{~m}$ until the observation of the first branch of the crown (Table 1).

Table 1: Characterization of the tree samples assessed herein by destructive and non-destructive approach in a concession area at the Jamari Flona, RO.

\begin{tabular}{llllllllll}
\hline \multirow{2}{*}{ Species } & \multirow{n}{*}{} & \multicolumn{3}{c}{$\boldsymbol{D B H}$} \\
\cline { 3 - 11 } & & $\boldsymbol{m i n}$ & mean & $\boldsymbol{m a x}$ & $\boldsymbol{s}$ & $\boldsymbol{m i n}$ & $\boldsymbol{m e a n}$ & $\boldsymbol{m a x}$ & $\boldsymbol{s}$ \\
\hline A. lecointei & 12 & 72.5 & 79.0 & 89.0 & 5.8 & 13.3 & 25.1 & 29.3 & 5.8 \\
D. excelsa & 9 & 56.6 & 104.8 & 128.0 & 25.7 & 9.0 & 17.4 & 24.2 & 4.6 \\
D. odorata & 12 & 59.4 & 76.5 & 93.2 & 13.1 & 13.3 & 16.6 & 19.3 & 2.0 \\
H. heterocarpum & 8 & 51.7 & 109.9 & 164.2 & 39.7 & 13.3 & 18.1 & 23.3 & 3.7 \\
\hline Sample & 41 & 51.7 & 92.5 & 164.2 & 29.6 & 9.0 & 19.3 & 29.3 & 5.1
\end{tabular}

Legend: $(D B H)$ diameter at $1.30 \mathrm{~m}$ from the soil base, in $\mathrm{cm} ;\left(h_{c}\right)$ commercial height, in $\mathrm{m}$; $(\mathrm{min})$ minimum value, in $\mathrm{cm}$ $(D B H)$ and $\mathrm{m}\left(h_{c}\right) ;($ mean $)$ mean value, in $\mathrm{cm}(D B H)$ and $\mathrm{m}\left(h_{c}\right) ;($ max $)$ maximum value, in $\mathrm{cm}(D B H)$ and $\mathrm{m}\left(h_{c}\right) ;(s)$ standard deviation, in $\mathrm{cm}(D B H)$ and $\mathrm{m}\left(h_{c}\right)$.

The procedures used were the destructive and non-destructive approaches to obtain the diameters along the trunks until the commercial height. The positions of diameter measurements along the trunk were taken every two meters from the DBH. Measurements below DBH, given their ease of collection, were done directly in both procedures.

For the non-destructive approach, the Criterion RD $1000^{\circledR}$ optical dendrometer was used, coupled to a $1.80 \mathrm{~m}$ Professional Photographic Universal Tripod, measuring the diameter up to the commercial height and at different distances between the measurer and tree, since this distancing was defined based on the possibility of measuring the commercial trunk with the lower presence of physical barriers such as understorey, crowns of other trees, vines and trees in close proximity.

After, the destructive approach was carried out with the direct measurement of diameter with a tree caliper, 15 days after the tree was felled, in compliance with the safety regulations of the concessionaire company. This elapse of time did not have influence on accuracy of the procedure tested, being in season of drought without any presence of rains.

\section{Analyses}

After the commercial trunk cubing $(1.30 \leq h i \leq h c)$ of each sample tree was generated the volume per $\log \left(v_{i}\right)$ and the commercial volume per tree $(v c)$ calculated by Smalian formula (SOARES et al., 2011) 
(Formulas 1 and 2).

$$
\begin{gathered}
v_{i}=\left(\frac{g_{i}+g_{i+1}}{2}\right) * l_{i} \\
v_{c}=\sum_{1}^{n} v_{i}
\end{gathered}
$$

\section{Formula 1}

\section{Formula 2}

Legend: $\left(v_{i}\right)$ volume with bark of the i-th $\log$, in $\mathrm{m}^{3} ;(g)$ transverse areas with bark obtained at the ends of the logs, in $\mathrm{m}^{2}$; (li) logs length, in $\mathrm{m}$; $\left(v_{c}\right)$ individual commercial volume with bark of each tree, considering $1.30 \leq h i \leq h c$, in $\mathrm{m}^{3}$.

To verify the homogeneity of variance of diameters, commercial and sectional volume along the trunk was used Bartlett test ( $p \leq 0.05)$ (BARTLETT, 1937) and for normality of data, Shapiro-Wilk test ( $p \leq 0.05)$ (ROYSTON, 1982). Then, the $t$ test $(p \leq 0.05)$ was performed for two independent samples to compare the measured diameters and volumes obtained from the destructive and non-destructive cubing.

Each tree was distributed into height classes, comprising at least three sections, two meters long each, from a height of $1.30 \mathrm{~m}$. The height classes were established as follows: Class I: $1.30 \leq h \geq 7.30 \mathrm{~m}$; Class II: $7.30<h \geq 13.30 \mathrm{~m}$; Class III: $h>13.30 \mathrm{~m}$ and commercial trunk: $1.30 \leq h \geq h_{c}$. To compare both measurement approach, residual graphs were assessed from the relative residues (Table 2), to verify possible trends in diameter and volume estimates obtained in the non-destructive approach.

To complement the graphic analysis, the following statistics were calculated in order to evaluate the estimates obtained in the adjustments for total data set and by classes: mean prediction error $(\bar{e})$ and percentage error $(\bar{e} \%)$, mean absolute difference $(M A D)$, mean square error of prediction (MSEP), relative error in prediction $(R E \%)$ and prediction coeficient of determination $\left(R p^{2}\right)$, presented in Table 2, with all the analyzes performed through the software R (R DEVELOPMENT CORE TEAM, 2017).

Table 2: Supplementary statistics concerning diameter and volume measurements of native species in a concession area at Jamari Flona, RO, by destructive and non-destructive approach.

\begin{tabular}{lr}
\hline Statistic & Estimator \\
\hline Relative residues (\%) & \\
Mean prediction error & $\left(\frac{Y_{i}-\hat{Y}_{i}}{Y_{i}}\right) \cdot 100$ \\
Percentage error & $\bar{e}=\frac{\sum_{i=1}^{n}\left(Y_{i}-\hat{Y}_{i}\right)}{n}$ \\
Mean absolute difference (MAD) & $\bar{e} \%=\frac{\bar{e}}{\bar{Y}} * 100$ \\
Mean square error of prediction $(M S E P)$ & $M A D=\frac{\sum_{i=1}^{n}\left|Y_{i}-\hat{Y}_{i}\right|}{n}$ \\
Relative error in prediction (RE\%) & $M E S P=\frac{\sum_{i=1}^{n}\left(Y_{i}-\hat{Y}_{i}\right)^{2}}{n}$ \\
Prediction coeficiente of determination $\left(R p^{2}\right)$ & $R E \%=\frac{\sqrt{M E S P}}{\bar{Y}} * 100$ \\
\hline
\end{tabular}

Legend: $\left(Y_{i}\right)$ is the diameter or volume of the $i$-th tree as measured by rigorous sampling after being felled in $\mathrm{cm}$ and $\mathrm{m}^{3}$; $\left(\hat{Y}_{i}\right)$ is the diameter and volume of the i-th tree measured by the non-destructive approach method in $\mathrm{cm}$ and $\mathrm{m}^{3} ;(n)$ number of observations; (di) $Y_{i}-\hat{Y}_{i} ;(\bar{Y})$ diameter or mean volume measured by the destructive approach method in $\mathrm{cm}$ and $\mathrm{m}^{3}$.

\section{RESULTS}

The variance homogeneity was verified by Bartlett test for diameters, considering the whole commercial trunk ( $p$-value 0.7613 ), as well as for the three comparison classes respectively ( $p$-value 0.9177 ; $p$-value $0.3862, p$-value 0.8175$)$. Regarding volume, the same behavior was observed, with homogeneous variances for the whole commercial trunk ( $p$-value 0.2857 ) and classes ( $p$-value $0.5198 ; p$-value $0.3406 ; p$ - 
value 0.8056$)$.

The Shapiro-Wilk test presented non normality of the data $\left(p\right.$-value $\left.\leq 1,03 \mathrm{e}^{-07}\right)$ for diameter and volume by classes and commercial steam. The diameters along the trunk were statistically different between the destructive and non-destructive approach from $13.3 \mathrm{~m}$ long position (Class III). In contrast, the diameters of classes I and II were similar, as were the volumes in all length classes and the commercial volume of the trunk (Table 3).

Table 3: Statistical diameter and volume $p$-values per height class and commercial trunks comparing destructive and non-destructive approach for native species at Jamari Flona, RO.

\begin{tabular}{lll}
\hline Class & Diameter & Volume \\
\hline Class I - $1.30 \leq h_{i} \geq 7.30 \mathrm{~m}$ & $0.3201^{n s}$ & $0.1833^{\text {ns }}$ \\
Class II - $7.30 \leq h_{i} \geq 13.30 \mathrm{~m}$ & $0.0572^{\text {ns }}$ & $0.0551^{\text {ns }}$ \\
Class III - $h_{i} \geq 13.30 \mathrm{~m}$ & $0.0369^{*}$ & $0.0802^{\text {ns }}$ \\
Commercial trunk - $1.30 \leq h_{i} \geq h_{c}$ & $0.0073^{*}$ & $0.3653^{\text {ns }}$ \\
\hline
\end{tabular}

Legend: $\left({ }^{n s}\right)$ non-significant difference $(p \geq 0.05) ;(*)$ significant difference $(p<0.05)$.

The residual dispersion of diameters along the trunk shows an increase of errors as the height increases, especially from $13.30 \mathrm{~m}$ greater tendencies of overestimation are shown. For the estimates of commercial trunk volume by the non-destructive approach, there is also a trend of overestimation of this variable, with a higher concentration of values close to $30 \%$ (Figure 2 ).

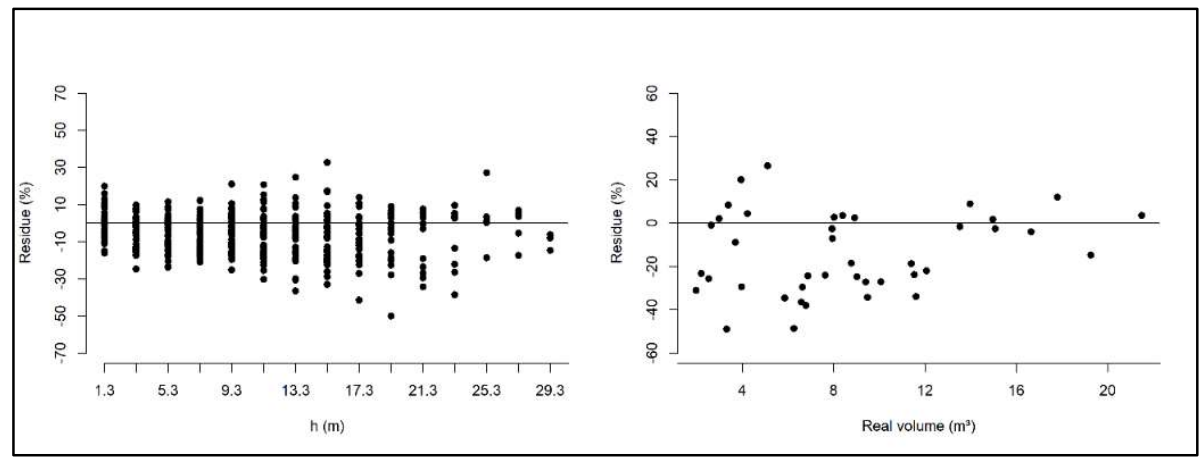

Figure 2: Percentage residues for diameters measured along the trunk and for commercial trunk volume, both by nondestructive approach cubing with the RD $1000^{\circledR}$ Criterion for native species of Flona do Jamari, RO.
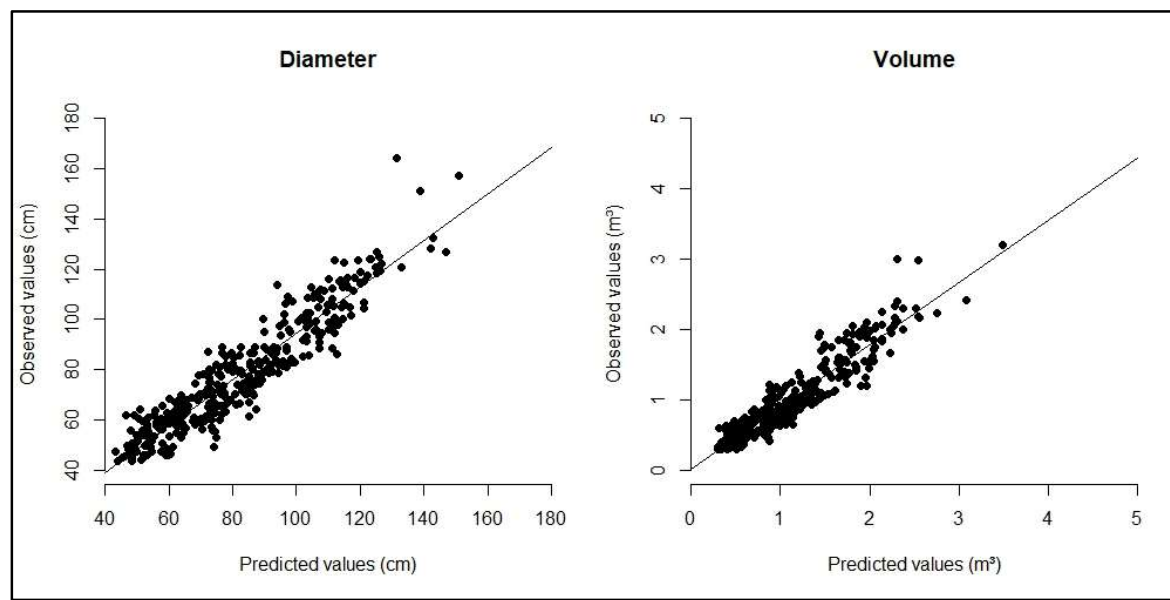

Figure 3: Distribution of the residue along the regression line for diameter and volume of native species measured by destructive approach (observed values) and non-destructive apprroach (predicted values) in concession area at Flona do Jamari, RO.

Even with the trend pattern previously seen, the residues show an accurate distribution with respect 
to the regression line, except for only a few values concentrated in the final parts of the lines representing the largest diameter and volumes (Figure 3).

The graphical analysis of volume residues by height classes (Figure 4), presented results similar to those described previously. The volumes were overestimated with greater homogeneity of errors in the lower heights (up to $7.30 \mathrm{~m}$ ). From $13.30 \mathrm{~m}$, residues with uneven distribution and error values of up to $100 \%$ can be observed for the smaller volumes, corresponding to those obtained for the upper trunk portions, where the smallest diameters are found.

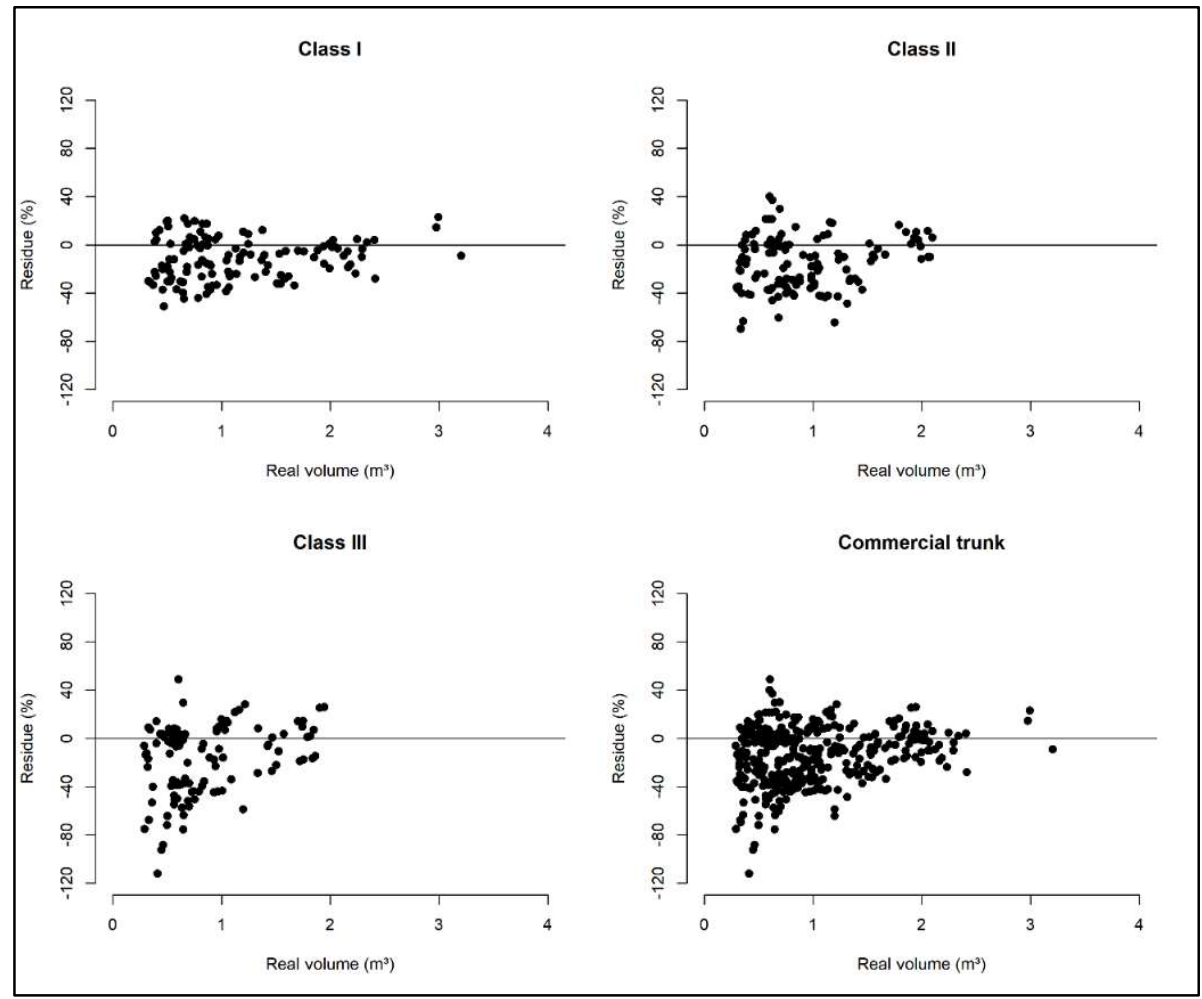

Figure 4: Residues percentage of non-destructive approach cubing using the Criterion $\mathrm{RD} 1000^{\circledast}$ dendrometer for volume per height class and for commercial trunks at Flona do Jamari, RO.

Legend: (Class I) $1.30 \leq h_{i} \leq 7.30 \mathrm{~m}$, (Class II) $7.30 \leq h_{i} \leq 13.30 \mathrm{~m}$; (Class III); $h_{i} \geq 13.30 \mathrm{~m}$, (Comercial trunk) $1.30 \leq h_{i} \leq$ $h_{c .}$

Based on complementary statistics we have the confirmation of tendency of overestimation given the average error values, especially from the second height class ( $h i \geq 7.30 \mathrm{~m}$ ), where it is verified for Class III height ( $h i \geq 13,30 \mathrm{~m}$ ) the highest error values, being higher than those found for all commercial trunk, indicating the influence of this class in the previously observed results that present statistical difference for diameter in the class III and commercial trunk for diameter (Table 4).

Despite the overestimation pattern observed, it was observed that values of coefficient of determination were higher than 0.7 for all height classes and commercial trunk, which represents in practice a satisfactory performance of measurement by the non-destructive approach and that this parameter presented values close to 0.9 in height class I, indicating greater accuracy of obtaining the variable diameter and volume in these positions using the Criterion ${ }^{\circledR}$ (Table 4). 
Table 4: Complementary statistics of diameter and volume per height class and commercial trunks for native species at Jamari Flona, RO.

\begin{tabular}{llllll}
\hline Estatistic & Variable & Class I & Class II & Class III & Commercial trunk \\
\hline \multirow{2}{*}{ Mean prediction error } & $d_{i}$ & -3.87 & -5.21 & -4.77 & -4.36 \\
& $v_{i}$ & -0.1204 & -0.1291 & -0.1018 & -0.1149 \\
\hline \multirow{2}{*}{ Percentage error } & $d_{i}$ & -4.63 & -6.96 & -6.72 & -5.64 \\
& $v_{i}$ & -10.8226 & -13.9688 & -12.2344 & -11.7526 \\
\hline \multirow{2}{*}{ Mean absolute difference } & $d_{i}$ & 6.61 & 7.68 & 8.01 & 7.27 \\
& $v_{i}$ & 0.1740 & 0.1905 & 0.1818 & 0.1798 \\
\hline \multirow{2}{*}{ Mean square error of prediction } & $d_{i}$ & 69.03 & 86.89 & 104.89 & 83.67 \\
& $v_{i}$ & 0.0506 & 0.0589 & 0.0558 & 0.0542 \\
\hline \multirow{2}{*}{ Relative error in prediction } & $d_{i}$ & 9.95 & 12.45 & 14.42 & 11.81 \\
& $v_{i}$ & 20.2185 & 26.2468 & 28.4118 & 23.8003 \\
\hline \multirow{2}{*}{ Prediction coeficiente of determination } & $d_{i}$ & 0.89 & 0.77 & 0.71 & 0.83 \\
& $v_{i}$ & 0.8760 & 0.7471 & 0.7400 & 0.8227 \\
\hline
\end{tabular}

Legend: $\left(d_{i}\right)$ is the diameter, in $\mathrm{cm}$; $\left(v_{i}\right)$ is the volume, in $\mathrm{m}^{3}$; (Class I) $1.30 \leq h_{i} \leq 7.30 \mathrm{~m}$, (Class II) $7.30 \leq h_{i} \leq 13.30 \mathrm{~m}$; (Class III); $h_{i} \geq 13.30 \mathrm{~m}$, (Comercial trunk) $1.30 \leq h_{i} \leq h_{c}$

\section{DISCUSSION}

Based on results it was possible to observe homogeneity of variances, but there was no data normality. This situation is expected for the data set, since the sample trees were randomly selected and following the measurement availability in the collection period. In addition, the diameter and volumetric distribution in native forests presents a non-normal pattern, but a negative exponential behavior (SOUZA et al., 2013), which confers greater variation among the values.

Regarding the comparison between the diameters, it was observed that the values obtained from $13.3 \mathrm{~m}$ in height had a direct influence on results obtained for the whole commercial trunk. It is also observed that the $\mathrm{t}$ statistic for diameter and volume in the class with heights between $7.3 \leq h i \leq 13.3 \mathrm{~m}$ were very close to the confidence limit used to indicate differences between means, suggesting that from this height $(7.30 \mathrm{~m})$ there were less accurate estimates and higher tendencies. This is confirmed by observing the dispersion of diameters at each measuring position along the trunk (Figure 2), where the lowest positions of the trunk have more homogeneous residues and as the height increases, it is also observed an increase of the residues, indicating an overestimation of diameters, especially for positions superior to $13.30 \mathrm{~m}$.

It is also observed that the increase in overestimation tendencies from the height of $13.30 \mathrm{~m}$ corroborates the hypothesis that the use limitations and greater errors of measurement with the optical dendrometer devices occur as the tree's height increase, showing in this sense, less accuracy in measurement of the variable diameter in highest heights.

The results observed in dispersion along the trunk were also verified in the study by Nicoletti et al. (2015), who described smaller tendencies for smaller trees and errors that do not exceed $10 \%$ in relation to real values. However, it should be noted that measurements were made only up to $8 \mathrm{~m}$ in height and for this study the measurements reached a height up to $29.30 \mathrm{~m}$, directly influencing the greater dispersion of errors found.

Considering the complementary statistics, the diameters and volumes for Class I $(1.30 \leq h i \leq 7.30 \mathrm{~m})$ and commercial trunk $(1.30 \leq h i \leq h c)$, were shown to have lower tendencies and amplitudes of errors, as well as a higher coefficient of determination that confirms better accuracy of non-destructive approach using 
Criterion $\mathrm{RD} 1000^{\circledR}$ in measurement of trunk lower parts.

In relation to Classes II and III of height $(7.30 \leq h i \leq h c)$, we can observe that these have higher error values and lower determination coefficients, confirming the influence of these two height classes on the observed tendencies results for commercial trunk that there was, mainly, in statistical values verified in (Table 3), that there was a statistically significant difference for the diameter variable in Class III and commercial trunk, and for Class II the value of $t$ statistic was close to the limit of significance used to evaluate difference or not statistical difference.

The tendency of overestimation observed in this study, for the two evaluated variables, which correspond to values of $-5.63 \%$ for diameter and $-11.7526 \%$ for volume, considering the entire commercial trunk, was also verified in the study by Dalla-Corte et al. (2016), which indicates, in this case, for the variable trunk volume, errors close to $10 \%$ in commercial plantation areas.

In this sense, the use of Criterion ${ }^{\circledR}$ in native species evaluated in natural forest area suggests that, due to the ecological and environmental conditions, there is a greater variation of variables, in relation to studies in forest plantations, where these variables present greater homogeneity. Thus, the results of this study indicate satisfactory performance of the device for cubing and obtaining dendrometric variables of native species, suggesting its use in both commercial and natural forest areas.

However, it is noteworthy that even when the variables are measured accurately, the device has limitations of use, as well as the natural environment also shows physical impediments and vegetation patterns that make it difficult to cubing the trees, especially in higher heights, where there is a greater occurrence of vines, overlapping of crowns and the increasing of visibility limitations of the device.

The tendency of higher errors with height increase was also verified by Silva et al. $(2012 ; 2017)$, evaluating the influence of sources of variation for the measurement of tree heights, indicate that, in general, the use of optical devices in forest measurement, present better results in the trunk lower parts and that the greater errors as the greater heights increase of trees that contemplate the upper strata of the forest, given the difficulties of visualizing the trunk.

Other relevant aspects for measurements with optical devices, such as Criterion ${ }^{\circledR}$, correspond to $^{2}$ horizontal distance between the operator and the tree and the trunk visibility, since, when using a photographic tripod, there are limitations on trunk visualization due the device inclination in the highest heights, it being emphasized that, this visualization also presents difficulties due to the environmental conditions, such as luminosity, presence of bark, buttresses in the lower heights, vines and surrounding trees.

It should be noted that, from the device installation to carry out the measurements, it must be fixed to obtain the base angle, reference point for determining the height and diameters along the trunk. If there are changes in manual measurement, there are changes in this angle causing errors in reading, in this sense, the use of tripod becomes fundamental, facilitating the device manipulation at the data collection and keeping the same fixed-point avoiding oscillations and measurement errors. However, Bonazza et al. (2015) considers that, when using the device fixed to a tripod of pre-established height, it is necessary a greater physical effort by the measurer to carry out the measurements, implying in non-ergonomic characteristics of 
the Criterion ${ }^{\circledR}$.

Regarding the observer distance from the tree, it is considered that this varied from $11 \mathrm{~m}$ to $24 \mathrm{~m}$, with an average of $20 \mathrm{~m}$, however, it is emphasized that even this average being higher than the average commercial height of $19.3 \mathrm{~m}$, due to diametric dimensions of the trees, the use of greater distances can be an alternative to minimize errors and facilitate the measurement activity.

Other studies prove the influence of horizontal distance on accuracy of measurements with optical devices, in which, Rodriguez et al. (2013) evaluating the use of Criterion ${ }^{\circledR}$ and other equipment as a nondestructive approach for the development of taper functions in pine stands in settlement in the north of Spanish Iberian Peninsula, and Bonazza et al. (2015) who verified the accuracy and efficiency of volumetric estimates obtained with Criterion ${ }^{\circledR}$ RD 1000 in commercial plantation of Pinus taeda L. in the southern of Brazil, considered that minor errors occurred when larger distances were used.

For the present study, this situation was also observed, however, in natural environments the determination of horizontal distance is conditioned by visibility issues, mainly due to the presence of barriers such as lianas and opening and/or closing of the device graduated bar.

It is also possible to observe the measurement difficulties in tortuous and irregular trunk, referring to positioning of the Criterion ${ }^{\circledR}$ reading bar at the trunk ends for diameters measuring. This fact presents for larger trees, difficulties in delimiting the trunk limits, due to limitations of flexibility of the graduation bar, in some situations larger, in others smaller than the actual diameter that was being visualized.

Considering not only the physical and ecological aspects of environment and operational device aspects, Williams et al. (1999) suggest that the use of dendrometers and optical devices involves the personal judgment of the observer regarding irregularities observed in the tree trunk and all the measurement steps that involve operator decision.

In general, the results obtained for the volumetric estimates, corroborate with the one suggested by Silva (2016), who cites the possibility of using Criterion ${ }^{\circledR}$ in forest inventories to obtain timber stocks of species native to the Amazon. The main equipment advantage is the possibility of measuring the standing tree, considering the non-authorizations of tree felling and/or samples with few individuals in cases of the need for precise estimates before the exploration stages, given the commercial importance and ecology of native forest species. In addition to serving as an alternative to data collection as a reliable basis to adjust mandatory volume models to forest management plans in the Amazon biome.

In this sense, Criterion ${ }^{\circledR}$ is used as an alternative for non-destructive forest measurement, even if it presents for greater heights limitations of diameter measurement. It is also considered that, for volumetric estimates of native species, the device can be used, since, it did not present statistical differences in relation to the destructive approach for the determination of trunk commercial volume. However, new approaches to studies by species and diameter classes are also suggested in order to minimize the errors of dendrometric estimates. 


\section{CONCLUSIONS}

The use of the Criterion device as a non-destructive approach was proven efficient regarding volume estimations for all tree trunk classes and for diameters up to $13.3 \mathrm{~m}$ in height. At greater heights, the Criterion presents certain limitations, mainly influenced by environment characteristics and the device's operability.

At the same time, the accuracy and precision of the Criterion $\mathrm{RD} 1000^{\circledR}$ for use in native environments such as the tropical Amazon forest is slightly higher than the one referenced in commercial sites for this instrument sale. Considering that in the present study was obtained for diameter accuracy of $7 \mathrm{~cm}$ with a precision of $83 \%$ and volume determination by the non-destructive approach it was obtained an accuracy of $0.18 \mathrm{~m}^{3}$ with a precision of $82 \%$.

ACKNOWLEDGMENTS: The Amata SA company and its collaborators of Jamari Flona. The Coordination for Improvement of Higher Education Personnel (CAPES) for scholarship granting.

\section{REFERENCES}

ALVARES, C. A.; STAPE, J. L.; SENTELHAS, P. C.; GONÇALVES, J. L. M.; PAROVEK, G.. Koppen's climate classification map for Brazil. Meteorologische Zeitschrift, v.22, n.6, p.711-728, 2013.

AMATA. Plano de manejo florestal sustentável categoria de PMFS: pleno. AMATA, 2009.

AMATA. Plano Operacional Anual 07: UPA 14 - 2017/2018. AMATA, 2017.

ARNEY, D. J.; PAINE, D. P.. Tree and stand volumes using height accumulation and telescopic Spiegel-relaskop. Forest Science, Washington, v.18, n.2, p.159-168, 1972.

BARTLETT, M. S.. Proceedings of the Royal Society of London. Mathematical and Physical Sciences, v.160, n.901, p.268-282, 1937. DOI:

http://dx.doi.org/10.1098/rspa.1937.0109

BONAZZA, M.; SAMPIETRO, J. A.; SILVESTRE, R.; NICOLETTI, M. F.; LIMA, G. C. P.; SILVA, A. L.; MORÉS, D. F.; RODRIGUES, A. L.. Accuracy of Non-Destructive Volumetric Estimates in Stands of Pinus taeda L. Australian Journal of Basic and Applied Sciences, v.9, n.31, p.71-79, 2015.

CARDOSO, D. J.; RIBASKI, J.. O uso do dendrômetro 'Criterion' para quantificação do volume por método não destrutivo. Colombo: Embrapa Florestas, Documentos 288. 2015.

CLARK, N. A.; WYNNE, R. H.; SCHMOLDT, D. L.. A review of past research on dendrometers. Forest Science. Washington, v.46, n.4, p.570-576, 2000.

CLIMATE-DATA. Clima: Itapuã do Oeste. CLIMATE-DATA, 2018.

COLPINI, C.; TRAVAGIN, D. P.; SOARES, T. S.; SILVA, V. S. M.. Determinação do volume, do fator de forma e da porcentagem de casca de árvores individuais em uma
Floresta Ombrófila Aberta na região noroeste de Mato Grosso. Acta Amazônica, Manaus, v.39, n.1, p.97-104, 2009. DOI: http://dx.doi.org/10.1590/S0044-59672009000100010

CYSNEIROS, V. C.; PELISSARI, A. L.; MACHADO, A. S.; FIGUEIREDO FILHO, A.; SOUZA, L.. Modelos genéricos e específicos para estimativa do volume comercial sob concessão na Amazônia. Scientia Forestalis, Piraciacaba, v.45, n.114, p.295-304, 2017. DOI: http://dx.doi.org/10.18671/scifor.v45n114.06

DALLA-CORTE, A. P.; SANQUETTA, C. R.; OLIVEIRA, K. A.; BEHLING, A.; COUTINHO, V. M.. Desempenho de diferentes equipamentos para mensuração de diâmetro a $1,30 \mathrm{~m}$, altura individual total, e volume do fuste em Cryptomeria japonica (Thunb. ex L. f.) D. Don.. Enciclopédia Biosfera, Goiânia, v.13, n.23, p.432-441, 2016.

FREITAS, A. G.; WICHERT, M. C. P.. Comparação entre instrumentos tradicionais de medição de diâmetro e altura com o Criterion 400. IPEF, Circular Técnica, n.188, p.1-7, 1998.

LASERTECH. Laser Technology, Inc. Criterion ${ }^{\circledR}$ RD 1000. LASERTECH, 2019.

MMA; IBAMA. Ministério do Meio Ambiente; Instituto Brasileiro do Meio Ambiente e dos Recursos Naturais Renováveis. Plano de Manejo da Floresta Nacional do Jamari. ICMBIO, 2005.

NICOLETTI, M. F.; CARVALHO, S. P. C.; BATISTA, J. L. F.. Revisão bibliográfica sobre métodos não-destrutivos de cubagem de árvores em pé visando à determinação da biomassa. Revista Científica Eletrônica de Engenharia Florestal, v.20, n.1, p.102-116, 2012.

NICOLETTI, M. F.; BATISTA, J. L. F.; CARVALHO, S. P. C.; CASTRO, T. N.. Exatidão de dendrômetros ópticos para determinação de volume de árvores em pé. Ciência Florestal, Santa Maria, v. 25, n. 2, p. 395-404, 2015. DOI: 


\section{http://dx.doi.org/10.5902/1980509818458.}

R CORE TEAM. R: A language and environment for statistical computing. R Foundation for Statistical Computing. Vienna: R Foundation for Statistical computing, 2017.

RODRIGUEZ, F.; LIZARRALDE, I.; FERNANDEZ-LANDA, A.; CONDE, S. S.. Non-destructive measurement techniques for taper equation development: a study case in the Spanish Northern Iberian Range. European Journal of Forest Research, v.133, p.213-223, 2013.

ROYSTON, J. P.. Algorithm AS 181: The W Test for Normality. Journal of the Royal Statistical Society. Series C (Applied Statistics), v.31, n.2, p.176-180, 1982. DOI: http://dx.doi.org/10.2307/2347986

SILVA, G. F.; OLIVEIRA, O. M.; SOUZA, C. A. M.; SOARES, C. P. B.; LEMOS, R.. Influência de diferentes fontes de erro sobre as medições de alturas de árvores. Cerne, Lavras, v.18, n.3, 2012. DOI: http://dx.doi.org/10.1590/S0104$\underline{77602012000300006}$

SILVA, N. S.; SANTANA, A. C.. Modelos de regressão para do volume de árvores comerciais, em florestas de Paragominas. Revista Ceres, Viçosa, v.61, n.5, p.631-636, 2014. DOI: http://dx.doi.org/10.1590/0034-737X201461050005

\section{SILVA, J. C.. Métodos de medição da altura e do volume}

comercial de árvores no bioma Amazônico. Dissertação (Mestrado em Ciências Florestais) - Universidade Federal do Espírito Santo, Vitória, 2016.

SILVA, G. F.; MÔRA, R.; CURTO, R. A.. Simulação de erros na medição de altura de árvores inclinadas com aparelhos baseados em princípios trigonométricos. Nativa, Sinop, v.5, n.5, p.372-379, 2017. DOI: http://dx.doi.org/10.5935/2318$\underline{7670 . v 05 n 05 a 12}$

SOARES, C. P. B.; PAULA NETO, F.; SOUZA, A. L. Dendrometria e inventário florestal. 2 ed. Viçosa: UFV, 2011.

THAINES, F.; BRAZ, E. M.; MATTOS, P. P.; THAINES, A. A. R.. Equações para estimativa de volume de madeira para a região da bacia do Rio Ituxi, Lábrea, AM. Pesquisa Florestal Brasileira, Colombo, v.30, n.64, p.283-289, 2010.

TONINI, H.; BORGES, R. A.. Equação de volume para espécies comerciais em Floresta Ombrófila Densa no sul de Roraima. Pesquisa Florestal Brasileira, Colombo, v.35, n.82, p.111117, 2015. DOI: https://doi.org/10.4336/2015.pfb.35.82.738

WILLIAMS, M. S.; CORMIER, K. L.; BRIGGS, R. G.; MARTINEZ, D. L.. Evaluation of the Barr \& Stroud FP15 and Criterion 400 Laser Dendrometers for Measuring Upper Trunk Diameters and Heights. Forest Science. Washington, v.45, n.1, p.53-61, 1999.

A CBPC - Companhia Brasileira de Produção Científica (CNPJ: 11.221.422/0001-03) detém os direitos materiais desta publicação. Os direitos referem-se à publicação do trabalho em qualquer parte do mundo, incluindo os direitos às renovações, expansões e disseminações da contribuição, bem como outros direitos subsidiários. Todos os trabalhos publicados eletronicamente poderão posteriormente ser publicados em coletâneas impressas sob coordenação da Sustenere Publishing, da Companhia Brasileira de Produção Científica e seus parceiros autorizados. Os (as) autores (as) preservam os direitos autorais, mas não têm permissão para a publicação da contribuição em outro meio, impresso ou digital, em português ou em tradução. 